\title{
Research on Relief Legal System for Lonely or Old Disabled in Ming and Qing Dynasties
}

\author{
Ye Ling \\ School of Marxism, Weinan Normal University; Shaanxi, Weinan 714000, China
}

\begin{abstract}
Keywords: Ming and Qing Dynasties; Lonely Old and Disabled; Relief Legal System
\end{abstract}
\begin{abstract}
Social relief is the lowest level of social security and has been the focus of successive dynasties since ancient times. Relief for the elderly and handicapped is an important embodiment of social legislation in the Ming and Qing Dynasties. The ruler of Ming and Qing dynasties paid more attention to the relief of the elderly living alone and the disabled, tried their utmost to implement the "benevolent government" concept, set up a relatively perfect supervision system and set up social relief agencies to standardize the relief objects in law. In order to help orphans and the disabled, it is not only the ideological issue that the support for the lone elderly and the disabled cannot leave without the support of funds and the relief legal system. In the actual operation process, we also need to improve policies and regulations, integrate social resources and mobilize the enthusiasm of members of the society. As the rulers of the Ming and Qing Dynasties were not influenced by the traditional political system, they did not improve the effective protection of the legal system of relief and did not further integrate the social resources. Therefore, the implementation of the relief legal effect on the "old-age disabled" was not ideal. Summarizing the experiences and lessons of the legal system of social relief during the Ming and Qing Dynasties has important implications for the construction of our country's modern relief legal system.
\end{abstract}

\section{Introduction}

In the history of China, there are long periods of charity and mutual aid. According to historical changes, charity activities are divided into three periods: first, religious charity in the Han and Tang Dynasties; second, government charity in the Song and Yuan Dynasties; third, social charity The Ming and Qing Dynasties erupted. In the Ming and Qing Dynasties, the law clearly stipulated the age-old or disabled-old, and the emergence of a large number of civil relief agencies promoted the rapid development of social relief. This article analyzes the situation of social relief in ancient China, mainly introduces the social relief system of lonely old and disabled during the Ming and Qing Dynasties, analyzes the relief legal system in the Ming and Qing dynasties in depth, and considers the existing problems in the legal system of lonely old and disabled disability relief in the Ming and Qing Dynasties, hope to give some inspiration to the social relief system today.

\section{The Summary of the Law of the Ming and Qing Dynasties "Adoption of Lonely Old"}

The system of social relief in the Ming and Qing Dynasties is already a regular policy. During the Ming dynasty, the rulers incorporated the policy of "adopting lonely old people" into the Ming dynasty and guaranteed the effective implementation of the relief policy. This is also the first time in history that the relief system has been incorporated into the legal provisions and has continued into the Qing Dynasty. During the Qing Dynasty, it was supplemented, which promoted the construction of social relief system to a great extent.

In the first year of Hongwu (1368), Emperor Zhu Yuanzhang, the founder of the Ming dynasty, decreed that "the poor and the poor, who are old and infamous after the Central Plains army, have more to lose, should send people to help the poor." [1] Opposition, but the Ming Taizu still announced the edict: "widowed widowed lonely disabled cannot be self-supporting, officer for the deposit." [2] to Hongwu five years (1372), in all counties to establish a home for the aged, and this is later nourishment hospital. Ming Taizu not only issued the imperial edict, but also wrote it into 
the legal provisions to standardize the behavior of solitary social relief and promote the development of the legal system of social relief, but also the beginning of the institutionalization of the ancient social relief law in our country. "Ming dynasty • household order - Adoption of loneliness" clearly states: "Where the widow lonely, every month to three grain rice grain, cloth every year to a certain amount, in the depositary. Overseer the censor, according to the prosecutor, often observe Hongwu thirty years (1397) promulgated the "law of the Ming dynasty," increased the adoption of lone articles, clearly states: "Where the widowed lonely and Tukai people, poverty, no dependents dependent, cannot exist, where the lawsuit should be adopted but not the adopter, cadre 60. If the government officials should be given less food and clothing to defend themselves against corruption, "[3] 51 these legal provisions were still used by the Qing dynasty and defined the standard of punishment. The Qing Qing Law Settlement By-laws added the express provision of "Where the Department is a prisoner, irrespective of ownership and stolen goods" [4]. Qing dynasty rulers pay more attention to the management of institutions such as the nongovernmental institute of relief. Compared with the Ming dynasty, the rulers of the Qing Dynasty improved the structure of the legal system of social relief and effectively protected the basic subsistence conditions of the lonely old and disabled, which is also a major aspect of our social relief system progress.

\section{The Emergence of Civil Relief Agencies}

Due to the rapid economic development in the late Ming Dynasty, there were problems of uneven wealth and class differentiation. In order to rejuvenate the ideal social system, some community leaders spontaneously set up charity organizations, such as the Tong Shan Association established by Yang Dongming in Yucheng, Henan Province. During that period, natural disasters occurred frequently, resulting in the displacement of people and the rulers' relief and incompetence. Therefore, these same benevolent associations with relief as their primary responsibility came into being. Scholar Liang Qizi's "Good and Educating: Philanthropic Organizations in the Ming and Qing Dynasties" did not find this reason convincing because every dynasty had natural disasters and man-made disasters, and only the Ming Dynasty had long-term charitable organizations. Liang Qizi thought that this was the change of concept. Before the 16th century, literati advertised their martial arts with poverty and poverty. In the late Ming Dynasty, the concept of wealth went deep into the heart and formed unique religious beliefs. Social elites are beginning to establish new values and rectify social order. [5]

The purpose of the Tongshan Society was to relieve the poverty of the lonely old people, but the people they were relieved of were not the really poor people, but the poor people who set standards. In this way, they were not simply charities, but education meaning of the organization. For example, the object of their relief is, first of all, those who have taken the literary gentry or abstinence, followed by pure and innocent poor seniors and the handicapped. Finally, there are no seniors who have abstained from abusing their laws and discipline and are in compliance with certain moral standards the main purpose of the people is to promote the moral concepts to the world.

\section{The Ming and Qing Dynasties Lonely Old Disabled Disability Model}

The ancient rulers have also paid more attention to the relief of the social vulnerable groups. Their purpose is to promote "benevolent government" and buy people's hearts. For example, the Six Disabilities Museum set up by Hsiao Tze-liang, a prince of Nan Qi, has its main role being to impoverish the poor and the sick. Liang established a solitary lonely garden with subsidies and a sickness-holding workshop during the Tang Dynasty. It is a well-established charity that mainly uses to support the poor, the elderly recuperate institutions; Futian Hospital established in the early Northern Song Dynasty, to the Song Dynasty this relief park has been all over the country. Yuan Dynasty also set up the home for the elderly, and give those who support widowhood and lonely disabled to give some grain subsidies. Until the Ming Dynasty, the Ming Taizu Xiazhao, and the development of "law of Ming Dynasty", led by the government to adopt loneliness, the Qing Dynasty continued the Ming Dynasty style of work, the adoption of the funds into the government's 
financial expenses.

All dynasties have similar relief agencies. The relief model is also based on hospital relief, provision of shelter for the aged and disabled people, medical treatment and other relief methods, and mainly to support the rights of survivals and the disabled. In the Ming and Qing Dynasties, the lonely old-age disability relief mode is also reeducation, that is, to protect the basic needs of lonely old and disabled, without teaching self-help ability, and its ultimate goal is still to achieve the ideal society advocated by Confucianism. Used, young, widowed, lonely, disabled people have their own support. "Until the late Qing Dynasty, influenced by the foreign churches and their cultural thoughts, it gradually changed the mode. According to the social conditions of the time, this relief system of "raising" can only maintain the basic standard of living of the rescued persons. Although the rulers aim of proclaiming "benevolent government" and buying people's hearts, they cannot fundamentally solve the problem of lonely old people with disabilities the problem of providing for the aged is what it means"

\section{The Reasons for the Limited Development of the Legal System of Social Relief during the Ming and Qing Dynasties}

In ancient China, the main revenue was local finance. The first priority of local finance was to maintain the normal operation of local governments. It should also be used for social relief. The original proportion was very low. Coupled with the frequent natural disasters, the government also relieved the famine the intensity is so great that there are even fewer rations left for orphans and the disabled. If a dynasty's treasury is full, then fiscal expenditures on lone old people and the disabled can be borne. If the fiscal deficit exists, then these people have no source of food rations. Even in the Ming Dynasty, in accordance with the law, the establishment of a nongovernmental institute and the adoption of lonely old and disabled people were affected by financial resources, so that although they entered the nourishment institute, they did not have any rations. The Qing Dynasty also began to limit the number of people with orphans and the handicapped. Generally, the number of places for supporting the people's health care in all counties and counties was first determined and reported to the ministry and eventually to the rulers. After the places were fixed, there was generally no increase in places.

The feudal dynastic rulers valued their own ruling order rather than the problem of their own existence, which is contrary to the real meaning of relieving lonely old people's disabilities. The ruler's concept of relief is not pure, which limits the development of social relief services for the aged and disabled. Ming Shen Shen Bang, "Wan Miscellaneous Miscellanies," said: "However, the case of Jingjing County, shall not be unauthorized admission, but the reform or state-owned ceremony, then the lower section of the county council ... ... no long-term, there is no constant, Life. "[7] This shows very directly that the implementation of the lonely and disabled remedy law is only a means of political rule. According to the records of the Qing Dynasty Sanitarium, "Historical Records of Zhu Zhongzhu in the Interior, Relief of the Interior," and "Cabinet Questions, Households, and Relief Classes" are all about the policy of saving the land and few historical materials about the institution Record. This shows that in the heart of the rulers, the role of relief for the aged and the disabled is to promote benevolence and is not an important government affairs. [8]

The ancient rulers of our country originally had impure motives for the relief of lone crippling and disability. Therefore, the related laws and policies formulated by the government have a certain degree of passivity and make the law itself have many problems. In addition, the exchange of information Inconvenience, state officials have different understanding of the policy, resulting in the implementation of the mistakes and difficulties in the operation. Although the Ming Dynasty enacted "Adoption of lonely old" law, but did not make it a clear definition of nor did it elaborate on the conditions of adoption, even for officials and other punitive measures are remedial measures started after the problem, with the corresponding Fuzziness and passivity. 


\section{The Enlightenment of the Social Relief Law System in Ming and Qing Dynasties to the Legal System of Chinese Relief}

The state should pay attention to social assistance because it is the redistribution of social wealth. Although the state possesses social resources that other social organizations cannot have, the entire social assistance system has to be managed through the participation and cooperation of the state, society and individuals. Nowadays, the state has shifted some responsibilities to the society, and many social organizations and individuals also voluntarily assume part of the relief responsibilities. Feudal dynasties, the government relief lonely old disabled purpose is to consolidate dynastic rule, nowadays our country social transition period, from big government, small society "to" small government, big society "change, traditional political rule mode no longer adapt to society Therefore, the system of social relief should be led by the state and all the people should be involved in the deployment of national and social resources. With the support of the state, the social relief system should give full play to the power of social charities and give full play to the strength of non-governmental charities. Strengthening the significance of modern aid. [8]

With the reform and opening up, China has a complete set of laws and regulations on social security such as minimum living allowance, medical aid and employment assistance, and the social aid legal system is also gradually taking shape. Since 2005, the drafting of the Law on Social Assistance has started to be prepared. In 2008, the draft of the Social Assistance Law was released. Until 2014, the State Council promulgated the Interim Measures for Social Assistance and established a relatively perfect legal system for social assistance. Which clearly government responsibilities, a reasonable division of financial burden and improve the social assistance legal system.

In the Ming and Qing Dynasties, the "recuperation and light remedy" assistance to the elderly and the disabled could not guarantee their basic rights of subsistence and gain more rights and development. This relief system was criticized by many enlightened people at the time and was gradually phased out until the Republican period. At present, the social assistance in our country has made tremendous progress. It has gradually shifted from the passive aid and assistance provided by the state to promoting the all-round development of individuals, providing more assistance to the elderly and the disabled, and giving them the ability to make their own living. For example, technical education for the handicapped, giving them basic needs of laborers, paying attention to spiritual and cultural satisfaction and guaranteeing that disabled persons still have the survival and development in line with human dignity.

During the Ming and Qing Dynasties, relatively complete legal provisions have been formed for the assistance of lone elderly and disabled people. The institution of recuperation is located in all counties in the Ming and Qing dynasties and provides certain guarantees to lonely old and disabled people. However, influenced by the rulers and institutions of the feudal dynasty, the social relief system in Ming and Qing dynasties gradually declined. Through combing the law of lone elderly disability relief in the Ming and Qing Dynasties and analyzing its problems, it can provide reference value for our country to perfect the legal system of lone elder and the disabled in the future.

\section{References}

[1] [Ming] Xu Xueju. The country dynasties • Household Ministry three • Rescue Famine [M] Beijing: Peking University Press, 1993.

[2] [Qing] Zhang Tingyu Ming Dynasty [M] Beijing: Zhonghua Book Company, 1974.

[3] Huai-feng point school: Da Ming law [M] Beijing: Law Press, 1999.

[4] Qing Dynasty ancestral compilation. Daqing law sets an example [M]. Beijing: Law Press, 1999.

[5] Liang Qizhi. Shi Shan and Education: Philanthropic Organizations in the Ming and Qing Dynasties [M]. Beijing: Beijing Normal University Press, 2013. 
[6] Xu Xiangshu. Taxi good act of China can act [A]. [Qing] Chen Zhongyi. Dynasty by the World Series III · Volume 35 [C]. Shanghai: Shanghai Book Company, 1901.

[7] [Ming] Shen Bang. Wan agency miscellany • Volume 11: too word • Nursery School Lonely Old [M] Beijing: Beijing Ancient Books Publishing House 1983.

[8] Wang Ying. Ming and Qing Dynasties legal aid for the elderly and the disabled legal system [J]. Lanzhou University 2016 master's degree thesis 